\title{
Metathoracic glands and associated evaporatory structures in Reduvioidea (Heteroptera: Cimicomorpha), with observation on the mode of function of the metacoxal comb
}

\author{
Christiane WEIRAUCH
}

American Museum of Natural History, Division of Invertebrate Zoology, Central Park West at 79th Street, New York, NY 10024, USA; e-mail: weirauch@amnh.org

Key words. Heteroptera, Reduviidae, metathoracic gland, morphology, defensive gland, dissemination of secretion

\begin{abstract}
Structures that assist in spreading secretions produced by the metathoracic glands were examined in Reduviidae and Pachynomidae (Heteroptera). The systematic distribution of a row of long and stout setae on the metacoxa, the metacoxal comb, was reinvestigated in a representative sample in both taxa. Observations on living Dipetalogaster maximus (Reduviidae: Triatominae) corroborated the interpretation of this metacoxal comb as an evaporatory device, which assists in atomizing the gland secretions. In addition to the metacoxal comb, a row of stout setae on the metacetabulum - a metacetabular comb - was found in several Reduviidae, which interacts with the metacoxal comb during rotation of the metacoxa. In addition to those atomizing devices, cuticular modifications surrounding the opening of the metathoracic gland, which presumably form evaporatoria, were discovered in Ectrichodiinae. The meshwork-like structure of this cuticle resembles the cuticular modifications found associated with the opening of the Brindley's gland in Reduviidae, but differs from the mushroom-like evaporatoria around the metathoracic glands in most Cimicomorpha and Pentatomomorpha. Thus, two fundamentally different mechanisms to spread secretions of the metathoracic gland atomization and evaporation - are present in Reduviidae.
\end{abstract}

\section{INTRODUCTION}

A complex gland system in the metathorax of the adult is one of the diagnostic and apomorphic features of Heteroptera (Carver et al., 1991). Apart from functioning e.g. in intraspecific aggregation and mating behavior, the secretions of this gland are defensive (Staddon, 1979, 1986). In the majority of Cimicomorpha and Pentatomomorpha the metathoracic glands are well developed, open through paired orifices laterally or ventrolaterally on the metepisternum (Carayon, 1971; Cobben, 1978), and the metepisternum is equipped with structures that are involved in the spreading of the gland secretions. In many Pentatomomorpha and Cimicomorpha these last structures comprise a scent gland groove ("gouttière odorifique" of Carayon, 1971), a peritreme, and in addition evaporatoria usually with mushroom-like sculpture (Johansson, 1957; Remold, 1962, 1963; Filshie \& Waterhouse, 1969; Johansson \& Bråten, 1970; Carayon, 1971; Staddon, 1979; see also Fig. 22).

The cimicomorphan group Reduvioidea comprises the small taxon Pachynomidae - 2 subfamilies with 4 genera (Carayon \& Villiers, 1968) - and the speciose and morphologically diverse Reduviidae with over 20 recognized subfamilies in more than 900 genera (Maldonado, 1990). Metathoracic glands are documented for numerous taxa in Reduvioidea, even though they seem to be consistently absent in certain groups (Carayon, 1962; Cobben, 1978). The apparent reduction of the metathoracic gland in Reduviidae compared to other cimicomorphan and to many pentatomomorphan groups (Carayon, 1971; Cobben, 1978) has given rise to speculation concerning their function in relation to the often well developed, dorsally located metathoracic Brindley's gland (Brindley, 1930; Carayon, 1962).

As to external disseminating devices associated with the metathoracic glands, Reduvioidea do not possess a well-defined scent gland groove (Carayon, 1971; Staddon, 1979), which caused Schuh \& Štys (1991) to conclude that its reduction is an apomorphic feature of the group. Furthermore, peritreme and evaporatory areas with mushroom-like cuticle appear to be absent in both taxa. Nevertheless, Reduvioidea possess structures that seem to be involved in the dispersion of scent gland secretions. Davis (1961) described a "row of bristles forming a comb located basally on the anterior lateral surface of each hind coxa" in several taxa of Reduviidae, and referred to this assemblage of setae as "hind coxal combs". When semirotating the hind coxa - for example during walking those bristles move over the margin of the coxal cavity and brush over the opening of the metathoracic gland. Davis (1961) assumed that the comb disseminated the gland secretions, an opinion reiterated by Schofield \& Upton (1978).

No other structures that might assist in spreading the metathoracic gland secretions have been described in Reduviidae and Pachynomidae. In this paper, the examination of structures associated with the opening of the metathoracic gland aims to expand the knowledge on such structures in Reduvioidea. In a first step, structure and location of the metathoracic gland were re-examined in Panstrongylus herreri (Triatominae). Then 71 species of Pachynomidae and Reduviidae were dissected, macerated, and examined light microscopically to establish absence or presence of the metathoracic gland. A larger 
taxon sample comprising 152 species, was used for light microscopical search for external evaporatoria. Scanning electron microscopical investigations on a more limited sample supplemented these results. The metacoxal comb was re-examined in 152 species of Pachynomidae and Reduviidae to refine the picture of its systematic occurrence. Observations on living specimens of Dipetalogaster maximus (Reduviidae, Triatominae) aimed to demonstrate the function of the metacoxal comb. The region surrounding the gland opening was examined for structures that might be involved in the dissemination of gland products. For comparative purposes, the area surrounding Brindley's gland opening was examined and illustrated for several representatives of Reduviidae.

\section{MATERIAL AND METHODS}

Light and scanning electron microscopical observation of the metathoracic gland and associated structures. Alcohol preserved specimens of Panstrongylus herreri Wygodzinsky were dissected and structures associated with the metathoracic gland illustrated using a NIKON SMZ1500 stereomicroscope with camera lucida equipment. For more detailed observation, the gland and attached structures were transferred to a slide and examined and illustrated using a Nikon Eclipse 80i compound microscope with camera lucida. Dried or alcohol preserved specimens were used for dissection and internal observation of the metathoracic gland in other taxa.

For external observation only, the metathorax surrounding the opening of the metathoracic gland, the metacoxal comb and the metacetabular comb in the remaining species of Reduviidae and in Pachynomidae were examined in dried or alcohol preserved specimens using either the NIKON SMZ1500 or a WILD HEERBRUGG 307800 stereomicroscope. Light microscopical observation allowed for assessment of shape and depth of the depression in Ectrichodiinae, as well as identification of modified cuticle (rough surface versus very smooth integument on the remaining pleuron). The exact structure of this modified cuticle (meshwork-like or not) however can only be recognized through use of the scanning electron microscope. For scanning electron microscopy (SEM) of the surroundings of the metathoracic gland opening and the opening of the Brindley's gland, the metathorax was dissected, cleaned in water, dried, coated with a BALZERS UNION SCD 014 (Freie Universität Berlin) or DENTON VACUUM DESKII (American Museum of Natural History), and observed on a PHILIPS SEM 515 (Freie Universität Berlin) or a HITACHI S-4700 (American Museum of Natural History).

Observation on living Dipetalogaster maximus (Uhler). Live male specimens of Dipetalogaster maximus were held with their legs pointing dorsad, which allowed for free movement of the legs, i.e. the rotation of the hind coxa. The venter of the insects was manipulated with forceps until a defensive response that involved secretion from the metathoracic glands was elicited.

Terminology. The "hind coxal comb" of Davis (1961) is here referred to as "metacoxal comb". The term "metacetabular comb" is created for the row of long setae on the metacetabulum that interacts with the metacoxal comb during rotation of the metacoxa.

Abbreviations used in the illustrations. acomb - (met)acetabular comb; apo - apophysis of furca; Brglo - Brindle's gland opening; c - coxa; ccomb - (meta)coxal comb; cocav - coxal cavity; gl -gland; glo - gland opening of metathoracic gland; glr - gland reservoir; mecut - meshwork-like cuticle; metcal - metacetabular callus; metdep - metacetabular depression; mucut - mushroom-like cuticle; om - opener muscle of metathoracic gland; oma - apodeme of opener muscle of metathoracic gland.

Material examined. The specimens examined for this project belong either to the American Museum of Natural History (AMNH), New York, the "Museum für Naturkunde, Zentralinstitut der Humboldt-Universität" (ZMHB), Berlin, Germany, the Muséum National d'Histoire Naturelle, Paris (MNHN), the Insect Collection of the "Universidade Federal do Rio Grande do Sul" (UFRG), Porto Alegre, Brazil, or were donated to the author by J.-M. Bérenger, D. Mahsberg, S. Roth, W. Sudhaus, S. Trenner, E. Wachmann, and A. Zwick. Living specimens of Dipetalogaster maximus were kindly provided by G. Nentwig (Bayer AG, Leverkusen).

The method(s) of observation for each taxon is given below, with external light microscopical examination for opening of the metathoracic gland, mushroom-like cuticle, metacoxal comb and metacetabular comb only $\left(^{\circ}\right)$, additional internal examination for the metathoracic gland $\left({ }^{\wedge}\right)$, and additional scanning electron microscopy $\left({ }^{\mathrm{a}}\right)$ are listed in Table 1.

PACHYNOMIDAE: Aphelonotinae: Aphelonotus sp. ${ }^{\circ}$, Peru (AMNH); Pachynominae: Camarochilus sp. ${ }^{\circ}$ (AMNH), *Pachynomus picipes Klug^, (ZMHB); Punctius alutaceus (Stal) ${ }^{\circ}$, South India (AMNH).

REDUVIIDAE: Centrocneminae: Centrocnemis sp. ${ }^{\circ}$, Bouthan (AMNH), *Neocentrocnemis sp. ${ }^{\circ}$ (ZMHB); Cetherinae: Caprocethera cave Breddin ${ }^{\circ}(\mathrm{ZMHB}),{ }^{*}$ Carcinomma $\mathrm{sp} .{ }^{\circ}$, Ghana (AMNH), ${ }^{*}$ Cethera musiva (Germar $)^{\wedge}$, Cetheromma telescopus Jeannel ${ }^{\circ}$ (ZMHB), *Eupheno pallens (Laporte) ${ }^{a}$, Chryxinae: Chryxus sp. ${ }^{\circ}$, Panama (AMNH); Ectrichodiinae: Afrocastra sp. ${ }^{\circ}$, Congo (AMNH), Antipula sp. ${ }^{\circ}$, Sri Lanka $(\mathrm{AMNH})$, Bayerus sp. ${ }^{\circ}$, South India (AMNH), ${ }^{*}$ Brontostoma colossus (Distant) ${ }^{\wedge}, B$. discus (Burmeister) ${ }^{\circ}$ (AMHH), Centraspis insignis Schouteden $^{\circ}(\mathrm{AMHH})$, Cimbus sp. ${ }^{\circ}$, Phillipines (AMNH), Cleptria sp. ${ }^{\circ}$, Congo (AMNH), Cricetopareis tucumana $(\mathrm{Berg})^{\circ}(\mathrm{AMNH})$, Daraxa nigripes Stål ${ }^{\circ}(\mathrm{AMNH})$, ${ }^{*}$ Ectrichodia crux Thunberg ${ }^{\wedge}$, Ectrichodia sp. ${ }^{\circ}$, Congo (AMNH), Ectrichodiella minima (Valdés) $^{\circ} \quad(\mathrm{AMNH})$, Ectrychotes andeae (Thunberg) ${ }^{\circ}(\mathrm{AMNH})$, Glymmatophora erythrodera (Schaum) ${ }^{\circ}$ (AMNH), Guionius sp. ${ }^{\circ}$, South India (AMNH), Haematorrhophus pedestris (Distant) ${ }^{\circ}$ (AMNH), Katanga etiennei Schouteden $^{\circ}$ (AMNH), K. linnavourii Villiers ${ }^{\circ}$ (AMNH), Katanga sp. ${ }^{\circ}$, Tanzania (AMNH), Maraenaspis hecqui Schouteden $^{\circ}$ (AMNH), Microstemmatoides atrocyanea

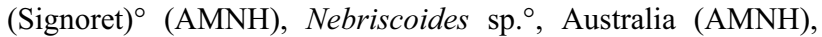
*Nularda nobilitata Stål^ ${ }^{\wedge}$. thoracica ${ }^{\circ}$ (de Jonck) (AMNH), Philodoxus principalis (Distant) ${ }^{\circ}$ (AMNH), Physorrhynchus sp. ${ }^{\circ}$, Liberia (AMNH), *Pothea lugens (Fabricius)^ (AMNH), Pothea sp. ${ }^{\text {, }}$ Amazonia (AMNH), Rhiginia sp. ${ }^{\circ}$, Brazil (AMNH), Santosia maculata (Fabricius) ${ }^{\circ}$ (AMNH), Scadra sp. ${ }^{\circ}$, Okinawa (AMNH), Schottus sp. ${ }^{\circ}$, Phillipines (AMNH), Sciaphilocoris ornata Miller ${ }^{\circ}$ (AMNH), Vilius sp. ${ }^{\circ}$, Sumatra (AMNH), Zirta hirticornis (Fabricius) ${ }^{\circ}$, ZMHB; *Zirta limbata Breddin $^{\wedge}$ (AMNH); Elasmodeminae: Elasmodema setigerum (Usinger) ${ }^{\circ}$ (ZMHB); Emesinae: Leistarchini: Ploiaria sp.^, Australien; Metapterini: Barce $\mathrm{sp} . \wedge ;^{\wedge}{ }^{*}$ Ghilianella filiventris Spinola^; Metapterus linearis Costa^; Ploiariolini: ${ }^{*}$ Empicoris xambeui (Montandon) ${ }^{\wedge}$, Hammacerinae: ${ }^{*}$ Homalocoris varius (Perty^, (AMNH), *Microtomus purcis (Drury)^ (AMNH), Microtomus sp. ${ }^{\circ}$, Brasilien; Harpactorinae: Apiomerini: Agriocleptes albosparsus (Stål) ${ }^{\circ}$ (ZMHB), Agriocoris flavipes (Fabricius) $)^{\circ}$ (ZMHB), Apiomerus barbiellini Costa Lima^, Campos Seabra \& Hathaway, *Apiomerus erythromelas Blanchard $^{\wedge}$, Apiomerus sp. ${ }^{\circ}$, Peru; *Heniartes flavicans (Fabricius) ${ }^{\wedge}$, ${ }^{*}$ Manicocoris rufipes (Fabricius) ${ }^{\wedge}$, ${ }^{*}$ Micrauchenus lineola Amyot \& Serville^${ }^{\wedge}$ * Ponerobia bipustulata Amyot \& Serville ${ }^{\wedge}$; 
Diaspidini: *Cleontes sp. $^{\circ} \quad$ (ZMHB); Diaspidius scapha

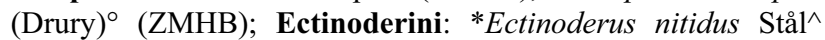
(ZMHB); Harpactorini: Amphibolus obscurus Reuter ${ }^{\circ}$ (ZMHB), ${ }^{*}$ Coranus subapterus (DeGeer) ${ }^{\wedge},{ }^{*}$ Cosmoclopius annulosus Stå $^{\wedge}$ (UFRG), Cosmoclopius intermedius Berg $^{\circ}$ (UFRG), Havinthus rufovarius Bergroth^, Isocondylus elongatus (Lepeletier \& Serville) ${ }^{\wedge}$, Montina distincta $\left(\right.$ Stål) ${ }^{\circ}$, Phonoctonus lutescens (Guérin \& Percheron) ${ }^{\wedge},{ }^{*}$ Pristhesancus plagipennis Walker ${ }^{\wedge}$, Rhynocoris iracundus (Poda)^, *Rhynocoris erythropus (Linné) $)^{\wedge}$, Sycanus sp. ${ }^{\circ}$, Indonesia; Zelus araneiformis Haviland ${ }^{\circ},{ }^{*}$ Zelus leucogrammus (Perty) ${ }^{\wedge}$; Rhaphidosomini: Rhaphidosoma sp. $^{\circ}$ (ZMHB); Tegeini: *Tegea atropicta Stål^; Holoptilinae: Holoptilini: *Ptilocnemus lemur (Westwood)^; Peiratinae: Ectomocoris sp. ${ }^{\wedge}$, Australia, Melanolestes morio (Erichson) ${ }^{\circ}$, *Peirates stridulus (Fabricius) $^{\wedge}$, Rasahus amapaensis Coscarón^ ${ }^{\wedge}$, Rasahus hamatus

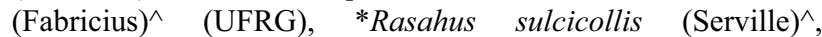
Sirthenea stria (Fabricius)^, Tydides rufus (Serville)^; Phymatinae: Phymatini: *Phymata monstrosa Fabricius`, Phymata praestans Handlirsch ${ }^{\wedge}$; Physoderinae: Paulianocoris alternatum $\left(\right.$ Signoret) ${ }^{\circ}(\mathrm{MNHN}){ }^{*}$ Physoderes sp.^ (AMNH); Pseudocetherinae Pseudocethera ifana Villiers ${ }^{\circ}$ (MNHN), Pseudocethera monodi Villiers $^{\circ}$, (MNHN); Reduviinae: *Acanthaspis sulcipes Signoret ${ }^{\wedge},{ }^{*}$ Centrogonus signatipennis (Reuter)^, ${ }^{*}$ Gerbelius ornatus Distant $^{\wedge}(\mathrm{AMNH})$, Inara $\mathrm{sp} .{ }^{\circ}$ $(\mathrm{AMNH}),{ }^{*}$ Microvarus conradti Jeannel^${ }^{\wedge}(\mathrm{AMNH}),{ }^{*}$ Nalata sp. ${ }^{\wedge}(\mathrm{AMNH}),{ }^{*}$ Neivacoris steini $\left(\right.$ Stål) ${ }^{\wedge}(\mathrm{AMNH}),{ }^{*}$ Opisthacidius chinai Lent \& Wygodzinsky^, *Paredocla cf. planquette Villiers^${ }^{\wedge}$, Pasira perpusilla (Walker) ${ }^{\circ}(\mathrm{AMNH}),{ }^{*}$ Platymeris biguttata (Linné)^, *Reduvius personatus (Linné)^, Reduvius tenuicornis $(\text { Jakovlev })^{\wedge}, \quad{ }^{*}$ Sphedanovarus camerunensis (Breddin) $)^{\wedge}(\mathrm{AMNH})$, Velitra sp. $^{\circ}$, Indonesia, Zelurus bucki Lent $\&$ Wygodzinsky $^{\circ}, *$ Zelurus spinidorsis $(\text { Gray })^{\wedge}(\mathrm{AMNH})$, Saicinae: ${ }^{*}$ Gallobelgicus typicus Distant $(\mathrm{AMNH})^{\wedge}$; ${ }^{*}$ Oncerotrachelus sp.^(AMNH); *Poytoxus sp. ${ }^{\circ}$, Australia; Salyavatinae: *Lisarda sp.^, Myanmar, *Platychiria umbrosa HerrichSchaeffer ${ }^{\circ}$ (AMNH), *Salyavata nigofasciata ${ }^{\circ}$ Costa Liman (AMNH); Sphaeridopinae: *Sphaeridops amoenus (Lepeletier \& Serville) ${ }^{\circ}(\mathrm{AMNH})$; Stenopodainae: *Canthesancus sp. ${ }^{\circ}$, India (AMNH), ${ }^{*}$ Ctenotrachelus sp. ${ }^{\circ}$, Brazil (AMNH); Diaditus sp. ${ }^{\circ}$, Brazil (UFRG), Kodormus bruneosus Barber ${ }^{\wedge} *$ Oncocephalus sp.^, France; *Pnirontis sp.^, Brazil, *Pygolampis

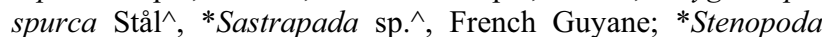
subinermis Stål^, *Thodelmus impicticornis Stål ${ }^{\circ}$ (AMNH); Triatominae: Rhodniini: *Rhodnius prolixus Stål^, Rhodnius pictipes Stål ${ }^{\circ}$, Triatomini: *Dipetalogaster maximus $(\text { Uhler })^{\wedge}$, *Eratyrus mucronatus Stål^, Panstrongylus geniculatus (Latreille) $)^{\wedge}, P$. herreri Wygodzinsky $(\mathrm{AMNH})^{\wedge}, P$. rufotuberculatus (Champion) $)^{\circ}$; ${ }^{*}$ Triatoma dimidiata (Latreille) ${ }^{\wedge}$; Triatoma infestans (Klug) ${ }^{\circ}$, Triatoma rubrofasciata $\left(\right.$ De Geer ${ }^{\circ}(\mathrm{AMNH})$; Tribelocephalinae: Opistoplatyni: ${ }^{*}$ Opistoplatys $\mathrm{sp}^{\wedge}{ }^{\wedge}$ (AMNH); Tribelocephalini: *Abelocephala sp. ${ }^{\circ}$ (AMNH); *Tribelocephala sp. ${ }^{\circ}$ (AMNH); Vesciinae: *Mirambulus morio Breddin $^{\circ}$ (AMNH), *Pessoaia argentina Wygodzinsky ${ }^{\circ}$ (AMNH), *Vescia spicula Stål $^{\circ}$ (AMNH); Visayanocorinae: ${ }^{*}$ Carayonia $\mathrm{sp} .{ }^{\circ}$, Australia (AMNH).

\section{RESULTS}

This study documents structures associated with the metathoracic gland in Pachynomidae and Reduviidae (Cimicomorpha, Heteroptera), which are involved in the dispersion or evaporation of metathoracic gland secretions. Apart from the metacoxal combs described earlier by Davis (1961), those structures comprise metacetabular combs and meshwork-like evaporatoria. Neither device was previously documented for Reduvioidea nor are they known in other Heteroptera.

After a short description of the metathoracic gland and its opening in Panstrongylus herreri (Triatominae), a survey of presence/absence of this gland in Reduviidae is provided, as are the systematic distribution of metacoxal and metacetabular combs. Meshwork-like evaporatoria are described in Ectrichodiinae and their systematic occurrence documented within this subfamily. Those morphological data are supplemented with observations on the atomizing mechanism of the metacoxal comb in living Dipetalogaster maximus (Triatominae).

\section{The metathoracic gland and its opening in Panstrongylus herreri}

The opening of the metathoracic gland in Panstrongylus herreri Wygodzinsky is located in a ventral position on the episternal margin of the metacetabulum (Fig. 1), somewhat anterior and lateral to the coxal cavity. It is best observed in ventral view (Fig. 2). The opening of the apophysis of the metathoracic furca has a much larger diameter than the very small gland opening, and is located median to it (Fig. 2). A narrow sulcus extends posterior and median of the gland opening, but has no connection to it (Fig. 2). The transversely oriented long and slender apodeme of the opener muscle of the metathoracic gland may be observed through the weakly sclerotized cuticle anterior to the sulcus (Fig. 2). Examined from the inside, the gland and the separate gland reservoir may be observed, as well as the apodeme of the opener muscle and the furcal apophysis (Fig. 3). Directly posterior to the transversely oriented opener muscle apodeme, a cuticular ridge runs parallel, which corresponds to the external sulcus described above (Fig. 3). Examination with the compound microscope allows for individual glandular units in the elongate and slender gland to be distinguished (Fig. 4). The reservoir, which is much larger than the gland, is membranous, and appears wrinkled (Fig. 4). It is devoid of glandular units. The muscle of the opener apodeme attaches on the distal portion of the apodeme (Fig. 4).

\section{The metathoracic gland and its opening in Pachynomidae and Reduviidae}

The metathoracic gland is present in Pachynomus picipes and in the majority of Reduviidae (Table 1). No metathoracic gland was found in this study in Emesinae, Harpactorinae, Holoptilinae, Saicinae and Visayanocorinae, and the gland opening was also determined to be absent (Table 1). Absence or presence of the gland opening is here interpreted as an indication of absence or presence of the gland itself in those instances where specimens could not be dissected.

In all examined species of Pachynomidae and Reduviidae the metathoracic gland opens on the metepisternal margin of the coxal cavity. The opening is very small (Figs 5-7, 8, 10-17, 25), much smaller than the furcal pit that invaginates anterior and/or medial to it (Figs 2, 6-8, $12,14-17,24,25)$. The opening is located either slightly 
lateral (Figs 5,6) or median (Fig. 7) to a longitudinal line drawn through the center of the coxal cavity. A median position of the gland opening was found in Hammacerinae (Fig. 7), Phymatinae and Centrocneminae. The gland opening is in a more lateral position in the remaining taxa studied (Figs 2, 5, 6).

The cuticle surrounding the opening of the metathoracic gland is often very smooth and polished, and in many taxa studied was formed into a protuberance, the metacetabular callus (Figs 12, 18, 24, 25). Although present in Pentatomomorpha and other Cimicomorpha, as e.g. Miridae (Fig. 22), peritreme and/or evaporatoria with mushroom-like evaporative cuticle are absent in Reduvioidea. Areas with modified cuticle that probably repre- sent evaporatoria - in this study only found among Ectrichodiinae - are described below.

\section{The metacoxal comb in Pachynomidae and Reduviidae re-examined}

The lateral margin of the metacoxa in Pachynomus picipes bears several rows of short stout setae, which together form a dense brush, here termed the metacoxal brush (Fig. 5). The metacoxa in other representatives of Pachynomidae, Aphelonotus sp. (Aphelonotinae), Punctius sp. and Camarochilus sp. (both Pachynominae) is devoid of such vestiture.

Many Reduviidae posses stiff erect or semierect setae on the proximal lateral margin of the metacoxa, which are here referred to as "metacoxal comb" (Figs 9-11, 14, 24,
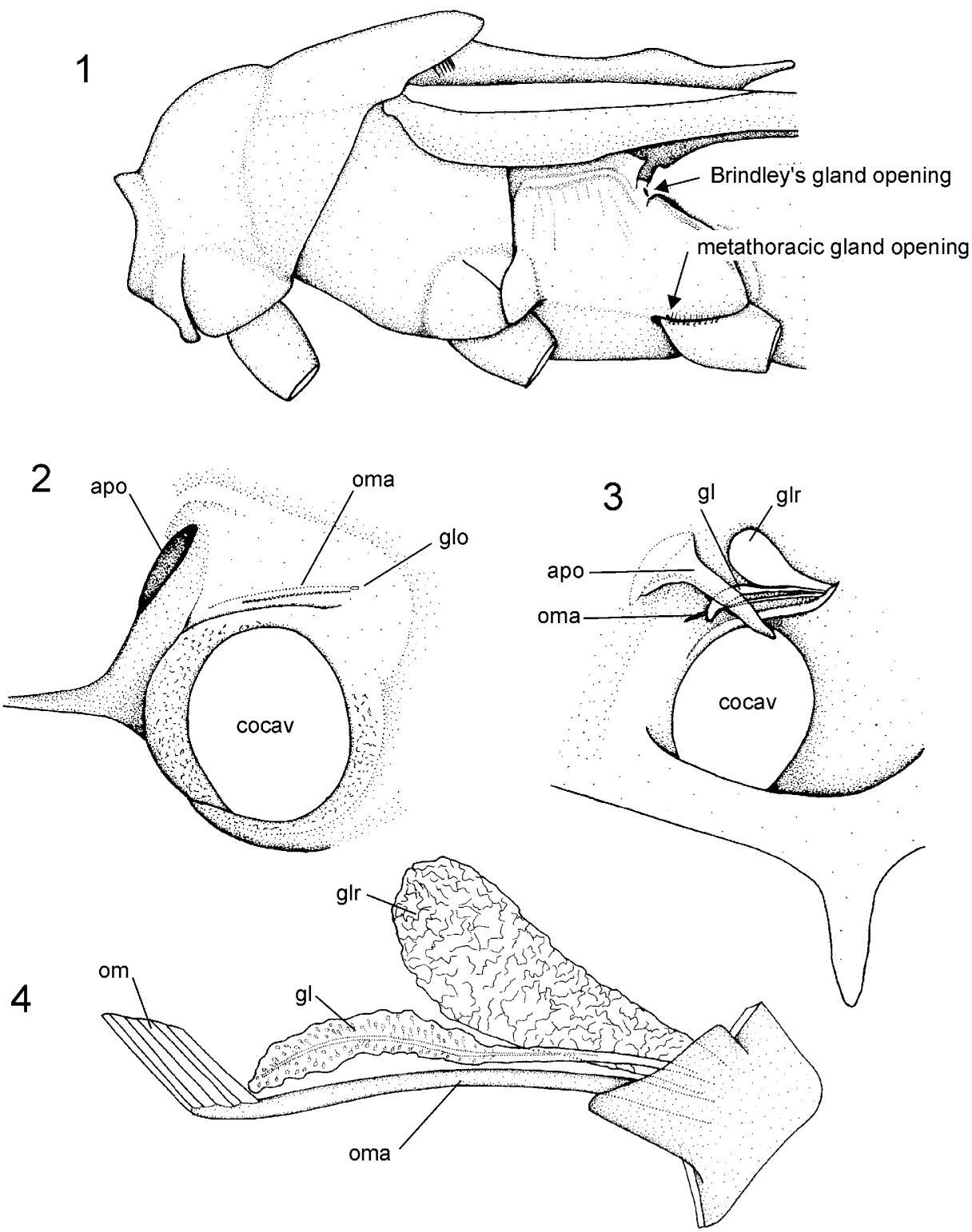

Figs 1-4. Thorax and metathoracic gland in Panstrongylus herreri (Triatominae). 1 - thorax in lateral view; 2 - exterior aspect of the metacetabulum, opening of metathoracic gland and furcal apophysis in ventral view; 3 - interior aspect of the metacetabulum, metathoracic gland and the furcal apophysis; 4 - internal aspect of the metathoracic gland showing the gland, its reservoir, and the opener muscle with its apodeme. 


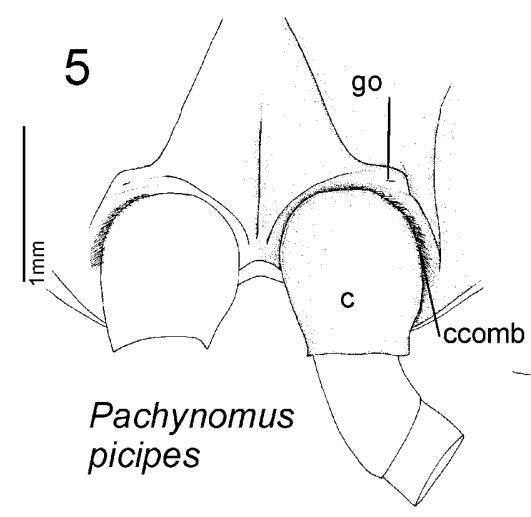

8

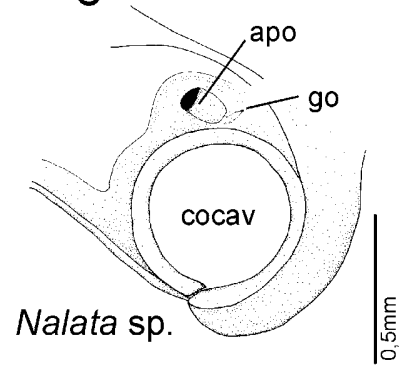

12

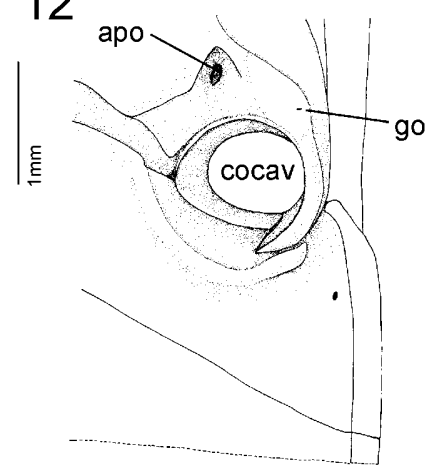

Canthesancus sp.

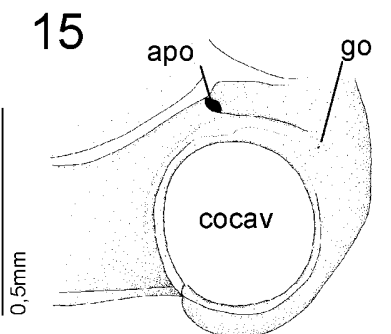

Mirambulus morio
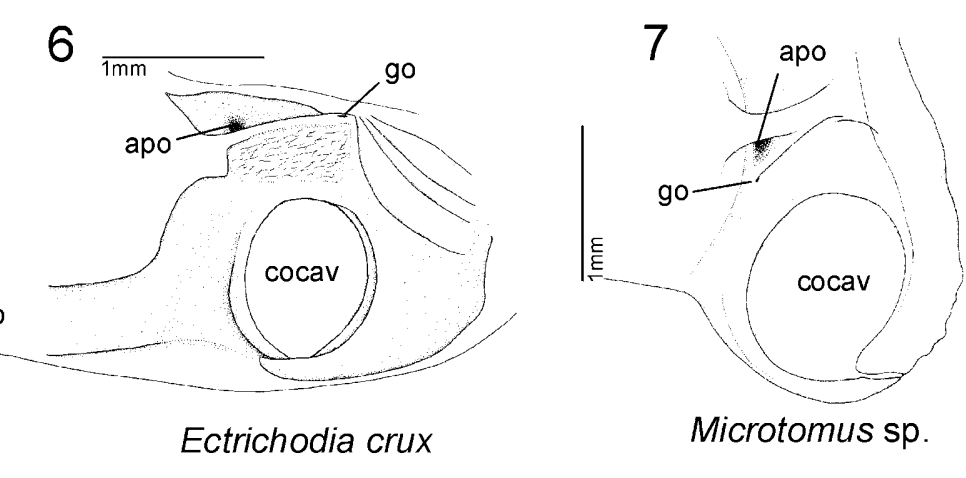

Microtomus sp.

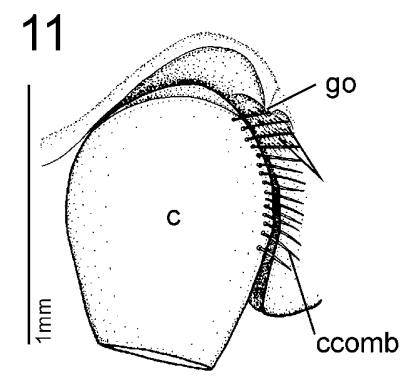

Salyavata nigrofasciata

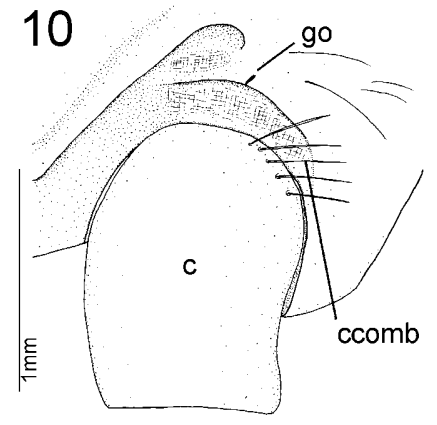

Sphaeridops amoenus

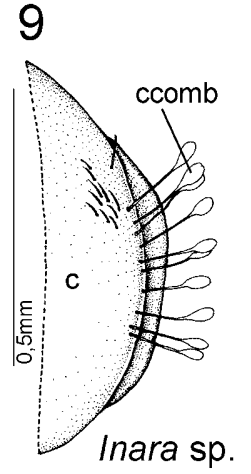

nara sp

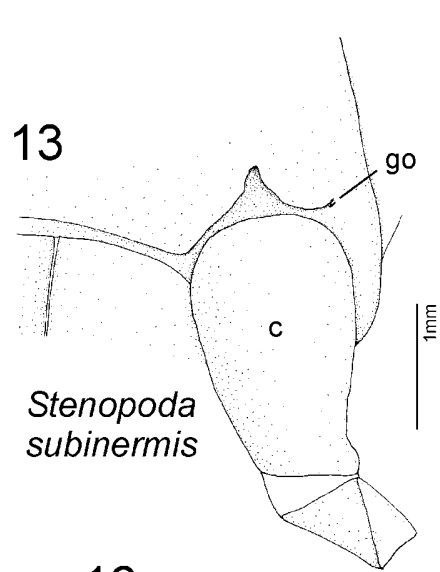

16

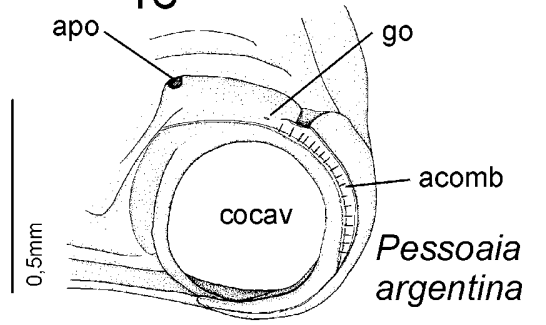

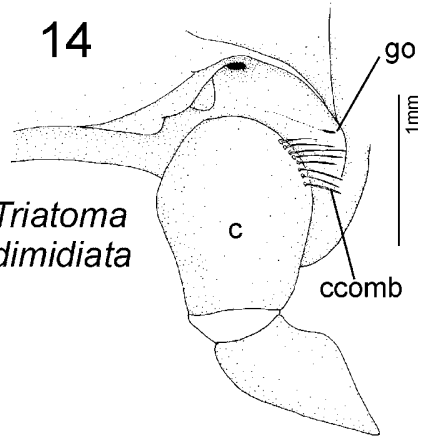

17

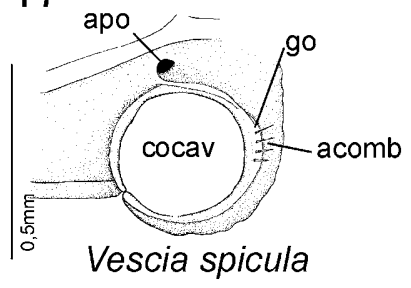

Figs 5-17. Structures associated with the opening of the metathoracic glands in Pachynomidae and Reduviidae. 5 - Pachynomus picipes, ventral view of the metathoracic; 6 - Ectrichodia crux (Ectrichodiinae), left metacetabulum and gland opening; 7 - Microtomus sp. (Hammacerinae), left metacetabulum and gland opening; 8 - Nalata sp. (Reduviinae), left metacetabulum and gland opening; 9 - Inara sp. (Reduviinae), left metacoxa, showing metacoxal comb; 10 - Sphaeridops amoenus (Sphaeridopinae), left side of metathorax in ventral view, showing metacoxa with comb and gland opening; 11 - Salyavata nigrofasciata (Salyavatinae), left side of metathorax in ventral view, showing metacoxa with comb and gland opening; 12 - Canthesancus sp. (Stenopodainae), left metacetabulum and gland opening; 13 - Stenopoda subinermis (Stenopodainae), left metacoxa, note the absence of a metacoxal comb; 14 - Triatoma dimidiata (Triatominae), left metacoxa, showing metacoxal comb; 15 - Mirambulus morio (Vesciinae), left metacetabulum and gland opening; 16 - Pessoaia argentina (Vesciinae), left metacetabulum with metacetabular comb and gland opening; 17 - Vescia spicula (Vesciinae), left metacetabulum with metacetabular comb and gland opening. 
TABLE 1. Absence and presence of metathoracic gland, opening of the metathoracic gland, metacoxal comb and metacetabular comb for selected taxa of Reduvioidea. The coding ( 0 and 1$)$ reflects the state of the observed character in a given species, but does not aim to polarize the characters as to their plesiomorphic or apomorphic condition; "?" signifies that the condition of the character is unknown.

\begin{tabular}{|c|c|c|c|c|c|}
\hline & & $\begin{array}{l}\text { metathoracic gland } \\
\text { present }(0) \text { absent }(1)\end{array}$ & $\begin{array}{l}\text { metathoracic gland opening } \\
\text { present }(0) \text { absent (1) }\end{array}$ & $\begin{array}{c}\text { metacoxal comb } \\
\text { present }(0) \text { absent }(1)\end{array}$ & $\begin{array}{r}\text { metacetabular comb } \\
\text { absent (0) present (1) }\end{array}$ \\
\hline Pachynomidae & Pachynomus picipes & 0 & 0 & 1 & 0 \\
\hline Centrocneminae & Neocentrocnemis sp. & $?$ & 0 & 1 & 0 \\
\hline \multirow{3}{*}{ Cetherinae } & Carcinomma sp. & 0 & 0 & 0 & 0 \\
\hline & Cethera musiva & 0 & 0 & 0 & 0 \\
\hline & Eupheno pallens & 0 & 0 & 0 & 0 \\
\hline \multirow[t]{5}{*}{ Ectrichodiinae } & Brontostoma colossus & 0 & 0 & 1 & 0 \\
\hline & Ectrichodia crux & 0 & 0 & 1 & 0 \\
\hline & Pothea lugens & 0 & 0 & 1 & 0 \\
\hline & Nularda nobilitata & 0 & 0 & 1 & 0 \\
\hline & Zirta limbata & 0 & 0 & 1 & 0 \\
\hline Emesinae-Metapterini & Ghilianella filiventris & 1 & 1 & 1 & 0 \\
\hline Emesinae-Ploiariolini & Empicoris xambeui & 1 & 1 & 1 & 0 \\
\hline \multirow[t]{2}{*}{ Hammacerinae } & Microtomus purcis & 0 & 0 & 1 & 0 \\
\hline & Homalocoris varius & 0 & 0 & 1 & 0 \\
\hline \multirow[t]{5}{*}{ Harpactorinae-Apiomerini } & Apiomerus erythromelas & 1 & 1 & 1 & 0 \\
\hline & Heniartes flavicans & 1 & 1 & 1 & 0 \\
\hline & Manicocoris rufipes & 1 & 1 & 1 & 0 \\
\hline & Micrauchenus lineola & 1 & 1 & 1 & 0 \\
\hline & Ponerobia bipustulata & 1 & 1 & 1 & 0 \\
\hline Harpactorinae-Diaspidini & Cleontes sp. & $?$ & 1 & 1 & 0 \\
\hline Harpactorinae-Ectinoderini & Ectinoderus nitidus & $?$ & 1 & 1 & 0 \\
\hline \multirow[t]{5}{*}{ Harpactorinae-Harpactorini } & Coranus subapterus & 1 & 1 & 1 & 0 \\
\hline & Cosmoclopius annulosus & 1 & 1 & 1 & 0 \\
\hline & Pristhesancus plagipennis & 1 & 1 & 1 & 0 \\
\hline & Rhynocoris erythropus & 1 & 1 & 1 & 0 \\
\hline & Zelus sp. & 1 & 1 & 1 & 0 \\
\hline Harpactorinae-Tegeini & Tegea atropicta & 1 & 1 & 1 & 0 \\
\hline Holoptilinae & Ptilocnemus lemur & 1 & 1 & 1 & 0 \\
\hline \multirow[t]{2}{*}{ Peiratinae } & Peirates stridulus & 0 & 0 & 0 & 0 \\
\hline & Rasahus sulcicollis & 0 & 0 & 0 & 0 \\
\hline Phymatinae-Phymatini & Phymata monstrosa & 0 & 0 & 1 & 0 \\
\hline Physoderinae & Physoderes sp. & 0 & 0 & 1 & 0 \\
\hline \multirow{12}{*}{ Reduviinae } & Acanthaspis sulcipes & 0 & 0 & 0 & 1 \\
\hline & Centrogonus signatipennis & 0 & 0 & 0 & 0 \\
\hline & Gerbelius ornatus & 0 & 0 & 0 & 0 \\
\hline & Microvarus conradti & 0 & 0 & 0 & 0 \\
\hline & Nalata sp. & 0 & 0 & 0 & 0 \\
\hline & Neivacoris steini & 0 & 0 & 0 & 0 \\
\hline & Paredocla cf. planquettei & 0 & 0 & 0 & 1 \\
\hline & Platymeris biguttata & 0 & 0 & 0 & 1 \\
\hline & Reduvius personatus & 0 & 0 & 0 & 0 \\
\hline & Sphedanovarus camerunensis & 0 & 0 & 1 & 0 \\
\hline & Opisthacidius chinai & 0 & 0 & 0 & 0 \\
\hline & Zelurus spinidorsis & 0 & 0 & 0 & 0 \\
\hline \multirow[t]{3}{*}{ Saicinae } & Gallobelgicus typicus & $?$ & 1 & 1 & 0 \\
\hline & Oncerotrachelus sp. & $?$ & 1 & 1 & 0 \\
\hline & Polytoxus sp. & 1 & 1 & 1 & 0 \\
\hline \multirow[t]{3}{*}{ Salyavatinae } & Lisarda sp. & 0 & 0 & 0 & 0 \\
\hline & Platychiria umbrosa & $?$ & 0 & 0 & 0 \\
\hline & Salyavata nigrofasciata & $?$ & 0 & 0 & 0 \\
\hline Sphaeridopinae & Sphaeridops amoenus & $?$ & 0 & 0 & 0 \\
\hline \multirow[t]{8}{*}{ Stenopodainae } & Canthesancus sp. & $?$ & 0 & 0 & 0 \\
\hline & Ctenotrachelus sp. & $?$ & $?$ & 1 & 0 \\
\hline & Oncocephalus sp. & 0 & 0 & 0 & 0 \\
\hline & Pnirontis sp. & 0 & 0 & 1 & 0 \\
\hline & Pygolampis spurca & 0 & 0 & 1 & 0 \\
\hline & Sastrapada sp. & 0 & 0 & 1 & 0 \\
\hline & Stenopoda subinermis & 0 & 0 & 1 & 0 \\
\hline & Thodelmus impicticornis & 0 & 0 & 0 & 0 \\
\hline Triatominae-Rhodniini & Rhodnius prolixus & 0 & 0 & 0 & 0 \\
\hline \multirow[t]{3}{*}{ Triatominae-Triatomini } & Eratyrus mucronatus & 0 & 0 & 0 & 0 \\
\hline & Dipetalogaster maximus & 0 & 0 & 0 & 0 \\
\hline & Triatoma dimidiata & 0 & 0 & 0 & 0 \\
\hline Tribelocephlinae-Opistoplatyni & Opistoplatys sp. & $?$ & 0 & 1 & 0 \\
\hline Tribelocephalinae-Tribelocephlini & Abelocephala sp. & $?$ & $?$ & 1 & 0 \\
\hline & Tribelocephala sp. & 0 & 0 & 1 & 0 \\
\hline Vesciinae & Mirambulus niger & $?$ & 0 & 0 & 0 \\
\hline & Pessoaia argentina & $?$ & 0 & 0 & 1 \\
\hline & Vescia spicula & $?$ & 0 & 0 & 1 \\
\hline$\underline{\text { Visayanocorinae }}$ & Carayonia sp. & 1 & 1 & 1 & 0 \\
\hline
\end{tabular}



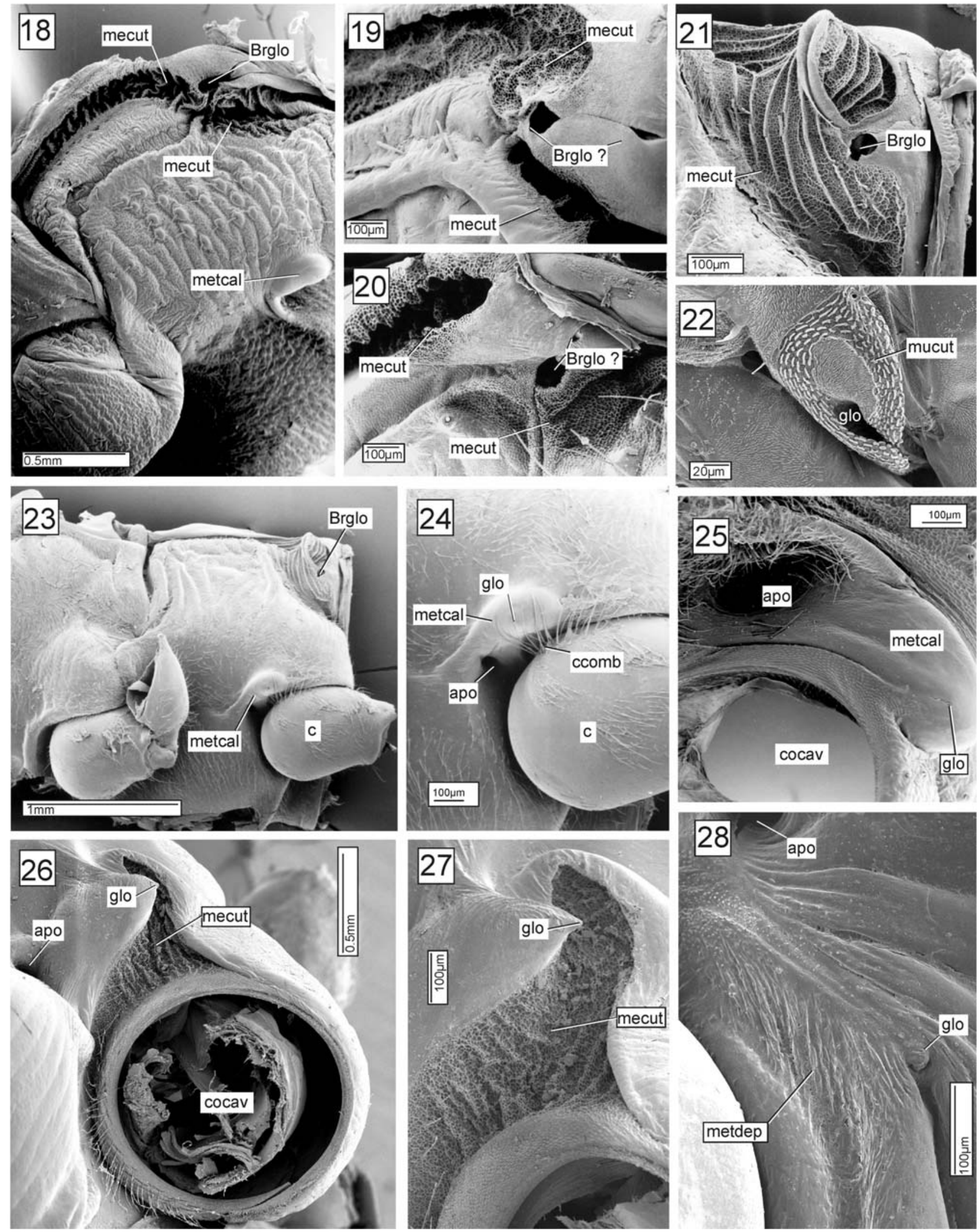

Figs 18-28. Structures associated with the opening of the metathoracic gland and the Brindley's gland. 18 - Rhodnius prolixus (Triatominae), metapleuron in anterolateral view showing the structures surrounding the openings of the metathoracic gland and the Brindley's gland. 19 - Panstrongylus geniculatus (Triatominae), opening of Brindley's gland with meshwork-like cuticle; 20 Microtomus sp. (Hammacerinae), opening of Brindley's gland with meshwork-like cuticle; 21 - Eupheno pallens (Cetherinae), spiral process with meshwork-like cuticle anterior to the opening of the Brindley's gland; 22 - undescribed Phylini, Miridae, mushroomlike cuticle surrounding the peritreme of the metathoracic gland; 23, $24-E$. pallens, 23 - metapleuron in lateral view, showing spiral process and metacetabular callus, 24 - metacetabular callus with gland opening and metacoxa with metacoxal comb; $25, R$. prolixus, metacetabular callus and gland opening; 26, 27 - Nularda nobilitata (Ectrichodiinae), 26 - metacetabulum in ventral view; 27 - close up of depression with meshwork-like cuticle and opening of the metathoracic gland; 28 - Pothea sp. (Amazonia), close up of shallow depression posterior to opening of the metathoracic gland. 
TABLE 2. Structure of evaporatoria in Ectrichodiinae, with the character coding $(0,1,2)$ reflecting the depth of the depression and its spacial extension. The characters are not polarized into apomorphic and plesimorphic conditions.

\begin{tabular}{|c|c|c|}
\hline Evaporatoria in Ectrichodiinae & $\begin{array}{c}\text { depression } \\
\text { absent }(0) \\
\text { shallow } \\
\text { (1) deep } \\
(2)\end{array}$ & $\begin{array}{l}\text { depression short, } \\
\text { only anterior }(0) \\
\text { groove extends } \\
\text { half way post (1) } \\
\text { all the way (2) }\end{array}$ \\
\hline Afrocastra sp. (Congo) & 2 & 1 \\
\hline Antipula sp. (Sri Lanka) & 2 & 2 \\
\hline Bayerus sp. (South India) & 1 & 0 \\
\hline Brontostoma colossus (Distant) & 1 & 0 \\
\hline B. discus (Burmeister) & 1 & 0 \\
\hline Centraspis insignis (Schouteden) & 2 & 0 \\
\hline Cimbus sp. (Phillipines) & 2 & 2 \\
\hline Cleptria sp. (Congo) & 2 & 1 \\
\hline Cricetopareis tucumana (Berg) & 2 & 2 \\
\hline Daraxa nigripes Stål & 2 & 2 \\
\hline Ectrichodia crux Thunberg & 1 & 0 \\
\hline Ectrichodia sp. (Congo) & 1 & 0 \\
\hline Ectrychotes andeae (Thunberg) & 1 & 0 \\
\hline $\begin{array}{l}\text { Glymmatophora erythrodera } \\
\text { (Schaum) }\end{array}$ & 1 & 0 \\
\hline Guionius sp. (South India) & 2 & 2 \\
\hline $\begin{array}{l}\text { Haematorrhophus pedestris } \\
\text { (Distant) }\end{array}$ & 0 & - \\
\hline Katanga etiennei Schouteden & 2 & 2 \\
\hline K. linnavourii Villiers & 2 & 2 \\
\hline Katanga sp. (Tanzania) & 2 & 2 \\
\hline Maraenaspis hecqui Schouteden & 2 & 0 \\
\hline $\begin{array}{l}\text { Microstemmatoides atrocyanea } \\
\text { (Signoret) }\end{array}$ & 2 & 2 \\
\hline Nebriscoides sp. (Australia) & 2 & 2 \\
\hline Nularda nobilitata Stål & 2 & 0 \\
\hline N. thoracica (de Jonck) & 2 & 0 \\
\hline Philodoxus principalis (Distant) & 1 & 0 \\
\hline Physorrhynchus sp. (Liberia) & 1 & 0 \\
\hline Pothea lugens (Fabricius) & 1 & 0 \\
\hline Pothea sp. (Amazonia) & 1 & 0 \\
\hline Rhiginia sp. (Brazil) & 1 & 0 \\
\hline Santosia maculata (Fabricius) & 2 & 0 \\
\hline Scadra sp. (Okinawa) & 2 & 0 \\
\hline Schottus sp. (Philippines) & 0 & - \\
\hline Sciaphilocoris ornata Miller & 2 & 2 \\
\hline Vilius sp. (Sumatra) & 0 & - \\
\hline Zirta hirticornis (Fabricius) & 2 & 1 \\
\hline Zirta limbata Breddin & 2 & 1 \\
\hline
\end{tabular}

Table 1). The metacoxal comb is absent in the taxa that do not possess a metathoracic gland, i.e., Harpactorinae, Holoptilinae, Emesinae, Saicinae and Visayanocorinae (Table 1). However, it is also absent in a number of taxa with a well developed metathoracic gland, notably all examined species of Ectrichodiinae, Hammacerinae, the remaining taxa of the Phymatine Complex, Physoderinae, and Tribelocephalinae, but also some species of Stenopodainae (Fig. 13) and Reduviinae (Table 1).

In most taxa examined, the metacoxal comb consists of one or more rows of simple erect stout setae of moderate to considerable length (Figs 10, 11, 14, 24). A deviation from these simple setae occurs in an unidentified species of Inara (Reduviinae), where the setae have enlarged, oval apices (Fig. 9).

When the metacoxa of macerated specimens is rotated manually, the tips of the setae of the metacoxal comb brush over the opening of the metathoracic gland.

\section{Observation on living Dipetalogaster maximus}

Dipetalogaster maximus possesses a well-developed metathoracic gland and a metacoxal comb (Table 1). Living male and female specimens of $D$. maximus, fixed in an inverted position allowing for free movement of all pairs of legs and manipulated with forceps, performed fast semi-rotations of their metacoxae. The release of secretions from the metathoracic gland through the minute gland opening could be observed. While semirotating the hind coxa, the tip of the metacoxal comb brushed over the gland opening, and the released secretion was dispersed forming a whitish vapor.

\section{Metacetabular comb and allied structures}

In addition to the metacoxal comb, certain taxa of Reduviidae possess a comb-like structure on the lateral, episternal rim of the metacoxal cavity, posterior to the opening of the metathoracic gland (Figs 16, 17). The stout and semierect setae of this comb point laterad. This row of setae is here referred to as metacetabular comb.

Among the taxa examined in this study, the metacoxal comb occurs only in certain Vesciinae (Pessoaia argentina, Vescia spicula) and Reduviinae (Acanthaspis sulcipes, Paredocla cf. planquettei and Platymeris biguttata) (Figs 16, 17). Pachynomidae and the remaining Reduviidae, including at least one Vesciinae (Mirambulus morio) and the majority of Reduviinae (see Table 1), lack this structure (Figs 12,15). Instead of a comb of stiff setae, Salyavata nigrofasciata (Salyavatinae) has a dense cover of fine setae in a corresponding position (Fig. 11). This field of setae is absent in other Salyavatinae examined.

Manual rotation of the macerated hind leg of Pessoaia argentina shows that the metacoxal comb and the metacetabular comb interact during rotation: the movable metacoxal comb rakes over the immovable metacetabular comb, resulting in an undulating movement of the row of setae of the metacoxal comb.

\section{Evaporatoria in Ectrichodiinae}

The metacoxal comb is absent in all Ectrichodiinae examined. The opening of the metathoracic gland is located lateral and anterior to the coxal cavity (Fig. 6). The cuticle surrounding the gland opening is unmodified compared to the cuticle of the remaining pleuron in Haematorrhophus pedestris (Fig. 42) and Vilius sp. (Fig. 56), and it shows only some faint ridges in Schottus sp. (Fig. 54). In all other species of Ectrichodiinae, the metacoxal rim posterior to the opening of the metathoracic gland is equipped with a depression that is usually lined with modified cuticle and shows various shapes and extensions (Table 2). The depression may be a more (Brontostoma discus; Fig. 32) or less (Bayerus sp.; Fig. 31) clearly defined groove (light gray to indicate shallow groove), its surface covered with slightly folded and ridged cuticle 


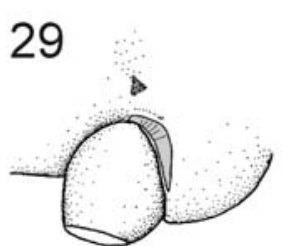

Afrocastra sp. (Congo)

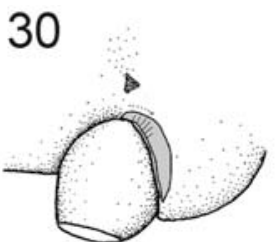

Antipula sp. (Sri Lanka)
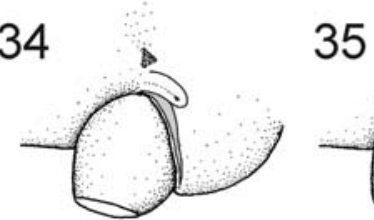

Cimbus sp. (Phillipines)
35

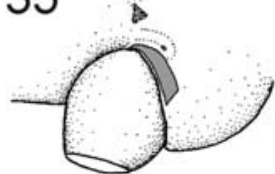

Cleptria sp. (Congo)

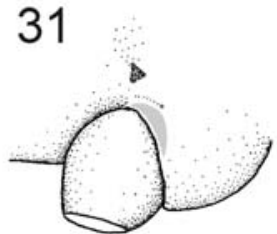

a) Bayerus sp. (South India)

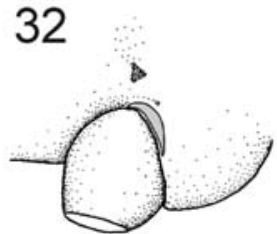

a) Brontostoma discus
33

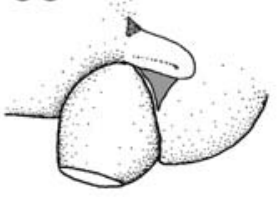

Centraspis insignis
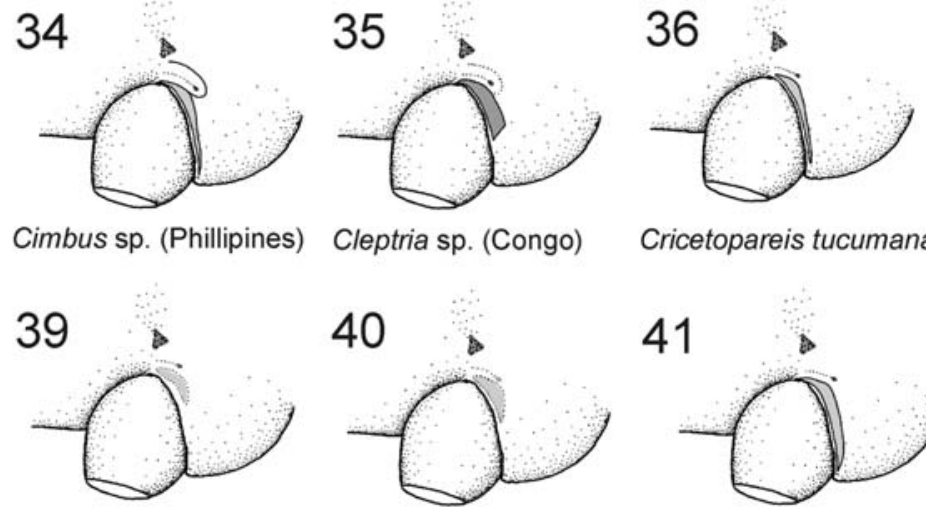

Cricetopareis tucumana

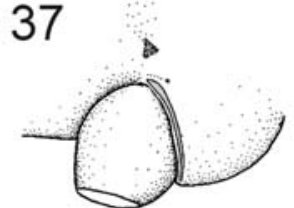

Daraxa nigripes

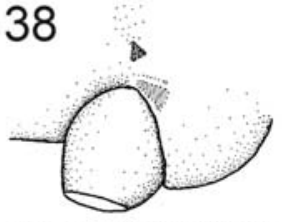

Ectrichodia sp. (Congo)

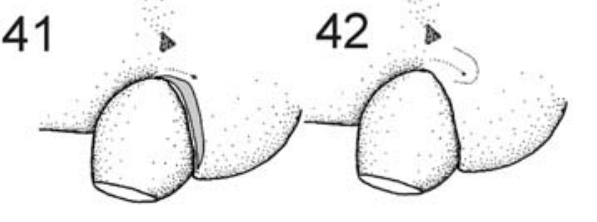

Haemaetorrhophus pedestris

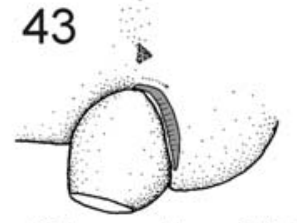

Katanga etiennei, K. linnavourii, Katanga sp. (Tanzania)

Ectrychotes andreae Glymmatophora erythrodera Guionius sp. (South India)

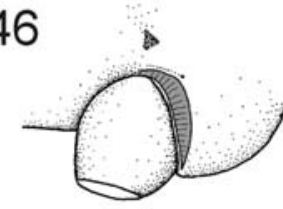

Nebriscoides sp. (Australia, NSW)
47

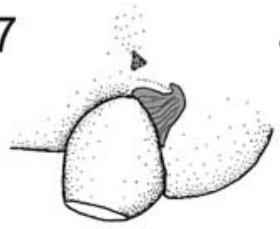

Nularda thoracica
48

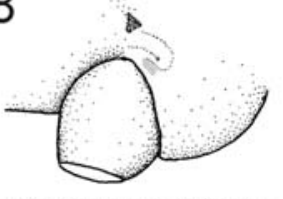

Philodoxus principalis

Maraenaspis lucqi

Microstemmatoides atrocyanea

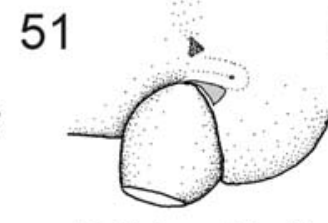

Rhiginia sp. (Brazil)

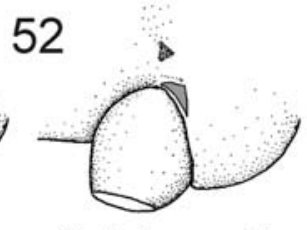

Santosia maculata
53

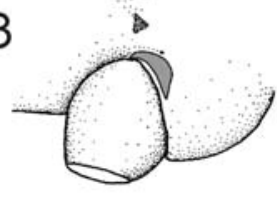

Scadra sp. (Okinawa)
Pothea sp. (Amazonia) (Liberia)
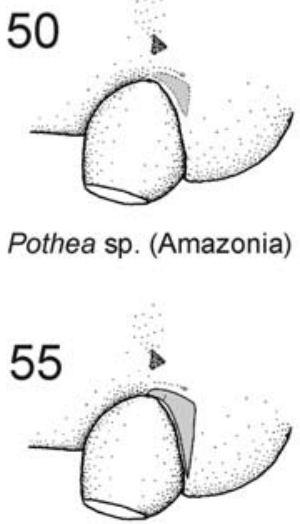

Schottus sp. (Philippines) Sciaphilocoris ornata

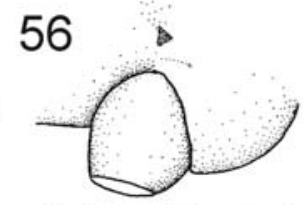

Vilius sp. (Sumatra)

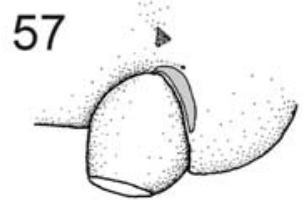

Zirta limbata

Figs 29-57. Schematic illustration of metathoracic evaporatoria in representatives of Ectrichodiinae, comprising a metacetabular depression (in gray) of varying shape and extent; (dark gray: deep depression; light gray: shallow depression; black margin: distinct outline, no black margin: indistinct margins, black lines indicate ridges traversing the groove) its cuticle may be smooth (Fig. 28) or lined with meshwork-cuticle (Fig. 27).

(Pothea sp.; Fig. 28). In other Ectrichodiinae, the depression or groove are of considerable depth (medium and dark gray to indicate relative depth of groove), often equipped with folds and modified cuticle (Table 2). The modified cuticle is very elaborate in Nularda nobilitata (Figs 26, 27), and the groove possesses a conspicuous meshwork-like surface.
Presence or absence of the depression, its shape, extent and depth folds, as well as presence of modified cuticle, were observed for 36 species of Ectrichodiinae representing 29 genera, and illustrated schematically (Figs 29-57).

Only Nularda nobilitata and other Ectrichodiinae among Reduvioidea posses grooves with meshwork-like 


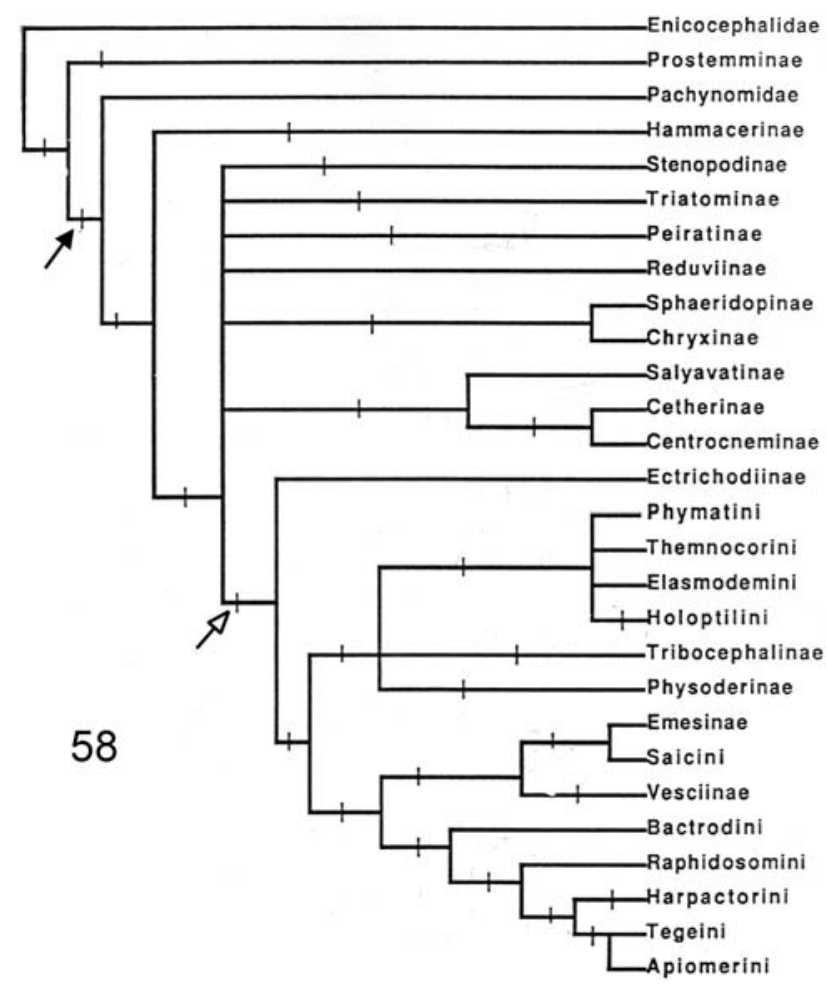

Fig. 58. Clayton's (1990) unpublished cladogramm of relationships within Reduvioidea. Gain and loss of the metacoxal comb according to her hypothesis are indicated by black (gain) and white (loss) arrows.

cuticle close to the metathoracic gland opening. However, cuticle with similar surface structure also occurs in other Reduviidae, but is associated with the opening of Brindley's gland (Figs 18-21). The meshwork-like cuticle may either be stretched out, as posterior and ventral to the opening of the Brindley's gland in Microtomus sp. (Fig. 20 ), or highly folded as it is in the corresponding positions in Rhodnius prolixus (Fig. 18). In its most elaborate form, meshwork-like cuticle covers the spiral-shaped process anterior to the opening of the Brindley's gland in Eupheno pallens (Fig. 21). Even though the performance of gland secretions on these areas with meshwork-like cuticle has not been closely observed, the location and structure of this specialized cuticle imply a role in the evaporation of gland secretions.

\section{DISCUSSION}

The metathoracic scent gland system in Reduvioidea is rather inconspicuous internally as well as externally compared to other Cimicomorpha and to Pentatomomorpha. Glands and reservoirs are small, the opening of the gland is minute, and structures thought to play a role in the dissemination of the gland secretions in other Cimicomorpha and Pentatomorpha - well developed scent gland groove, peritreme and evaporatorium with mushroom-like surface structure - are absent. Even though the metathoracic glands are completely reduced in certain taxa of Reduviidae, notably Harpactorinae and Emesinae and allies, they are present in the majority of the remaining reduviid taxa, and, more interestingly, Reduviidae have evolved structures to disseminate the secretions of this gland that are unknown in other Heteroptera. Apart from the metacoxal comb previously described by Davis (1961) and reexamined in this study, which is present in numerous higher-rank taxa of Reduviidae, those structures include a previously undescribed comb on the rim of the coxal cavity, the metacetabular comb, present in only a few species. A simple experiment on living specimens of one reduviid demonstrated that the metacoxal comb atomizes the released secretion as previously postulated by Davis (1961) and Schofield \& Upton (1978). An interaction of the metacoxal comb with the comb on the metacetabulum might influence this atomizing effect. Instead of this spraying device, depressions with meshwork-like modified cuticle were found in numerous species of Ectrichodiinae close to the opening of the metathoracic gland. Their surface structure resembles the one around the opening of the Brindley's gland, and a role in evaporation of gland secretions appears likely.

Primary homology of certain structures, such as the evaporatoria in Ectrichodiinae or the metacoxal comb in many taxa of Reduviidae, is postulated in the present study. Those characters should be subjected to testing in future cladistic analysis of higher rank groupings in Reduviidae involving a wider range of character complexes.

\section{The metacoxal comb in Reduviidae and the metacoxal brush in Pachynomidae}

Davis (1961) combined several subfamilies of Reduviidae as "Piratine complex" due to the presence of the metacoxal comb in those taxa. According to Davis (1961) this group comprises - besides Peiratinae - Cetherinae, Chryxinae, Emesinae, Salyavatinae, Reduviinae, Saicinae, Sphaeridopinae, Stenopodainae, Triatominae and Vesciinae. The observations presented in this study show that some of the groups contained in this assemblage lack the metacoxal comb. None of the Emesinae and Saicinae examined bears a hind coxal comb, and it is absent in Visayanocorinae (Table 1). Among Reduviinae, Sphedanovarus camerunensis lacks the metacoxal comb and only some of the examined taxa of Stenopodainae possess it (Table 1).

Based on a suggestion by Miller (1956), Clayton (1990) stated that Eurylochus bellator should not be included within Sphaeridopinae and gave absence of a fossula spongiosa and absence of a metacoxal comb - present in other taxa of Sphaeridopinae - as arguments. All Sphaeridopinae examined in this study including Eurylochus bellator possess a well developed metacoxal comb, apart from the fact that Sphaeridopinae is well defined as a group, e.g., on the basis of the unique shape of the pronotum.

Even though the survey of the metacoxal comb in Reduviidae provided here is more detailed than previously published information, at least the situation in Reduviinae and Stenopodainae deserves more attention, and is of potential systematic value. 
In her unpublished cladistic analysis of reduviid subfamilies, Clayton (1990) (Fig. 58) coded a metacoxal comb as present for Pachynomidae, based on her observation on Pachynomus picipes. In Clayton's (1990) analysis, the most parsimonious distribution for this character within Reduvioidea resulted in treatment of the metacoxal comb as a plesiomorphic feature within Reduviidae. Metacoxal combs are unknown in other groups of Cimicomorpha and in Pentatomomorpha. This study found an assemblage of short setae on the metacoxa in $P$. picipes, and its absence in representatives of the three remaining genera of Pachynomidae. The somewhat different composition of the brush in $P$. picipes and the comb in Reduviidae - a brush of numerous rows of short setae vs. a row of rather long stout setae - may imply that the two structures are not homologous. The absence of the brush in the remaining Pachynomidae - undisputedly a monophyletic group - questions the homology of the two structures even further. In a future cladistic analysis of Reduvioidea, the homology of the two structures should be rigorously tested.

\section{The metacoxal comb as atomizer}

Davis (1961) assumed the metacoxal comb to be a dissemination device for metathoracic gland secretions. This hypothesis was corroborated in the present study by observations on living Dipetalogaster maximus, which atomized the secretions with the comb through rotation of the hind coxa. The insect was in a very artificial position during the experiment, its dorsal side turned down, but semi-rotation of the hind coxae does also occur when the animal is walking or running. Assuming that the secretion is a defense aimed, for example, against small mammals, the atomizing effect could be exerted while escaping from a predator, but also while the reduviid is attacked and helplessly turned on its back.

\section{The metacetabular comb}

The metacetabular comb described in this study occurs only in a few taxa of Reduviidae, with all of them also possessing the metacoxal comb. In the same way the two combs brushed against each other in the macerated specimen of Pessoaia argentina studied, a similar interaction might also occur while the living insect is, e.g., walking. As to the function of the metacetabular comb, two interpretations seem likely that should be further tested. The brushing might have a cleaning function, so that the metacoxal comb may efficiently carry out its atomizing function. A second hypothesis might be that the interaction of the two combs enhances the atomizing performance.

Only some Vesciinae and a few species of Reduviinae possess a metacetabular comb. Future systematic analyses of Reduviidae will clarify if the combs are homologous, or if such structures have arisen more than once within the taxon.

\section{Evaporatoria in Ectrichodiinae}

At least one group of Reduviidae has evolved a different mechanism for dissemination of metathoracic gland products. Other than in the groups that bear a metacoxal comb, and atomize secretion, the surroundings of the metathoracic gland opening in many Ectrichodiinae are reminiscent of evaporative surfaces. Not only is this area shaped into a depression or groove in many species, but the surface of this depression is frequently folded and lined with cuticle with a meshwork-like surface. These three features (depression, folds, meshwork-like fine structure) enlarge the surface of this particular area of the metepisternum. Meshwork-like cuticle is known in Reduviidae anterior or posterior to the opening of the Brindley's gland where it is also located in grooves or depressions and equipped with folds (Figs 19-21). Given the association of this type of cuticle with the openings of Brindley's glands, and at least in the case of Ectrichodiinae also the metathoracic glands, their evaporatory function seems evident. However, future observations on living specimens should corroborate this assumption.

About 111 genera are described in Ectrichodiinae at present (Maldonado, 1990), yet the understanding of relationships within the group is limited (Dougherty, 1995). At least one representative of 29 genera was examined in the present study. Judging from this sample, the structure of the evaporatorium varies considerably among genera, but seems to be rather constant within a genus - the three species of Katanga observed do not show any difference (Fig. 43). A more extended survey of the evaporatorium in Ectrichodiinae, combined with additional character complexes, might be a useful character complex for future suprageneric cladistic analysis within this taxon.

ACKNOWLEDGEMENTS. For loan of specimens I would like to thank J. Deckert (Museum für Naturkunde, Berlin) and R.T. Schuh (American Museum of Natural History, New York), as well as those mentioned in Material and Methods who donated specimens. R.T. Schuh kindly commented on the manuscript. The results presented were obtained in part while working on my $\mathrm{PhD}$ thesis, at the Freie Universität Berlin. I wish to thank W. Sudhaus for supervising my thesis, the "AG Evolutionsbiologie" for discussion, and "Nachwuchsförderungsgesetz des Landes Berlin" (NaFöG), Anette Kade Graduate Student Fellowship Program at the American Museum of Natural History, "Berliner Programm zur Förderung der Chancengleichheit für Frauen in Forschung und Lehre", and Parsyst for financial support.

\section{REFERENCES}

BRINDLEY M.D.H. 1930: On the metasternal scent glands of certain Heteroptera. Trans. Entomol. Soc. Lond. 78: 199-207.

CARAYON J. 1962: Observations sur l'appareil odorifique des Hétéroptères. Particulièrement celui des Tingidae, Vianaididae et Piesmatidae. Cahiers Nat. (N.S.) 18: 1-16.

CARAYON J. 1971: Notes et documents sur l'appareil odorant métathoracique des Hémiptères. Ann. Soc. Entomol. Fr. (N.S.) 7: 737-770.

CARAYON J. \& Villiers A. 1968: Étude sur les Hémiptères Pachynomidae. Ann. Soc. Entomol. Fr. (N.S.) 4: 703-739.

Carver M., Gross G.F. \& Woodward T.E. 1991: Hemiptera. In: CSIRO (ed.): The Insects of Australia. Cornell University Press, Ithaca, NY, pp. 429-510.

Clayton R.A. 1990: A Phylogenetic Analysis of the Reduviidae (Hemiptera: Heteroptera) with Redescription of the Subfamilies and Tribes. Dissertation, The George Washington University, Washington D.C., 191 pp. 
CobBen R.H. 1978: Evolutionary Trends in Heteroptera. Pt. 2. Mouthpart-Structures and Feeding Strategies. Mededelingen Landbouwhogeschool 78-5. H. Veeman, Wageningen, Netherlands, $407 \mathrm{pp}$.

DAVIS N.T. 1961: Morphology and phylogeny of the Reduvioidea (Hemiptera: Heteroptera). Part II. Wing venation. Ann. Entomol. Soc. Am. 54: 340-354.

DougherTy V. 1995: A review of the new world Ectrichodiinae genera (Hemiptera: Reduviidae). Trans. Am. Entomol. Soc. 121: $173-225$.

Filshie B.K. \& Waterhouse D.F. 1969: The structure and development of surface pattern on the cuticle of the green vegetable bug Nezara viridula. Tissue Cell 1: 367-385.

JoHANSSON A.S. 1957: On the functional anatomy of the metathoracic scent glands of the milkweed bug, Oncopeltus fasciatus (Dallas) (Heteroptera: Lygaeidae). Norsk. Entomol. Tidssk. 10: 95-109.

Johannson A.S. \& BRÅten T. 1970: Cuticular morphology of the scent gland areas of some heteropterans. Entomol. Scand. 1: $258-262$.
Maldonado J. 1990: Systematic catalogue of the Reduviidae of the world. Caribbean J. Sci., Spec. Ed., University of Puerto Rico, Mayagüez, x +694 pp.

MiLLER N.C.E. 1956: Biology of the Heteroptera. Leonard Hill Books, London, $162 \mathrm{pp}$.

Remold H. 1962: Über die biologische Bedeutung der Duftdrüsen bei den Landwanzen (Geocorisae). Z. Vgl. Physiol. 45: 636-694.

Remold H. 1963: Scent-glands of land bugs, their physiology and biological function. Nature 198: 764-768.

Schofield C.J. \& Upton C.P. 1978: Brindley's scent glands and metasternal scent glands of Panstrongylus megystus. Rev. Bras. Biol. 38: 665-678.

SсHUH R.T. \& ŠTYS P. 1991: Phylogenetic analysis of cimicomorphan family relationships (Heteroptera). J. N.Y. Entomol. Soc. 99: 298-350.

Staddon B.W. 1979: The scent glands of Heteroptera. $A d v$. Insect Physiol. 14: 351-418.

Staddon B.W. 1986: Biology of scent glands in the HemipteraHeteroptera. Ann. Soc. Entomol. Fr. 22: 183-190.

Received March 31, 2005; revised and accepted June 19, 2005 